\title{
PARTY SPACE IN CRACOW AND WARSAW: PARTYING AND CONFLICTS
}

\author{
GRZEGORZ IWANICKI, ${ }^{1}$ ANNA DŁUŻEWSKA ${ }^{2}$ \\ 1 Maria Curie-Skłodowska University in Lublin \\ e-mail: greg.iwanicki@gmail.com \\ 2 Kazimierz Wielki University in Bydgoszcz, Maria Curie-Skłodowska University in Lublin \\ e-mail: dluzewska.a@gmail.com
}

\begin{abstract}
\begin{tabular}{l|l} 
JEL CODES & Z19, Z32, Z39
\end{tabular}
KEYWORDS clubbing, Cracow, party tourism, stag tourism, Warsaw
\end{abstract}

ABSTRACT Central European cities became popular party tourism destinations after the enlargement of the European Union in 2004. Cracow and Warsaw became one of the most popular such destinations among Polish cities. With the increase in the number of tourists in both cities the incomes of local entrepreneurs increased, especially owners of restaurants, bars and clubs, but over time the presence of many drunken, behaving improperly tourists from abroad became the cause of conflicts with the local population and other tourists. These conflicts occur mainly in public spaces, near places with the highest concentration of bars and clubs. Such spaces can be called a before party zones (for bars and pubs) and party or clubbing zones (for clubs). This paper presents such zones in Cracow and Warsaw.

\section{Introduction}

Party tourism can be divided into two main types: clubbing tourism and stag tourism. The first type is associated with a sociological phenomenon of clubbing, which emerged in the mid-1980s, involving participation in electronic music events. Initially such clubbing parties were organised illegally, e.g. in abandoned warehouses or in the open air on the city outskirts (Malbon, 1999). Over time, these events became legal, and at the beginning of 1990s the island of Ibiza became 
the most popular clubbing destination. In the next years other resorts in the Mediterranean such as e.g. Mallorca or Ayia Napa (on Cyprus) also gained popularity (Malbon, 1999; Sonmez, Apostolopoulos, Teocharous, Massengale, 2013).

The second main type of party tourism, stag tourism, has a slightly shorter history closely related to the development of the low-cost airline market and city break travels (Dunne, Flanagan, Buckley, 2010). This type of tourists goes to European cities usually at the weekend for pre-wedding party in several clubs and pubs. Most of them are British citizens (Boazmann, 2010; Thurnell-Read, 2012).

Since the accession of Central and Eastern European countries to the EU, stag and clubbing tourists speaking a foreign language could be heard in the streets of large cities in those states. These are in particular very noisy groups of tourists from the United Kingdom. The behaviour of foreign tourists, often under the influence of alcohol, poses a problem for many clubbing centres (e.g. Hughes, Allen, 2009; Smith, Puczko, 2010; Nofre, Giordano, Eldridge, Martins, 2017). In many cases, cities attempt to change their tourist image and they introduce regulations to reduce the arrivals of party tourists (e.g. Hadfield, 2009; Colomb, Novy, 2016; Nofre et al., 2017).

The main aim of the article is to define conflict areas of public space related to the party tourism infrastructure in Cracow and Warsaw, based on delimitated clubbing and before party zones. The additional aim is an attempt to find reasons of the evident differences that exist between Warsaw and Cracow party tourism-related issues.

\section{Conflicts in party zones}

Many cities have undergone a revitalization process in recent decades, as a part of which they have transformed their centers into places of night life entertainment lasting until the early hours of the morning (e.g. Lovatt, O'Connor, 1995; Bavinton, 2010). Such changes in the urban space have also led to changes in the ways of spending free time, especially among young people who have begun to spend time in dance clubs and pubs (e.g. Malbon, 1999; Laughey, 2006; Goulding, Shankar, 2011). As a result of these changes, city centers have transformed into night life areas, which at the same time have initiated some negative phenomena widely described in both sociological and medical literature. These phenomena relate in particular to health issues related to casual sex or to abuse of alcohol, drugs or other intoxicating substances by club-goers (e.g. Briggs, Tutenges, Armitage, Panchev, 2011; Ravn, 2012; Sonmez et al., 2013).

With the emergence of low-cost airlines, some European cities became a popular weekend destination for party tourists, which contributed to the initiation of another negative aspect related to clubbing: conflicts between foreign party-goers and local residents. In particular, this problem concerns loud, drunken and badly behaving groups of British tourists (Boazmann, 2010; ThurnellRead, 2012). Few attempts of describing such conflicts (and other negative aspects) compared to the existing clubbing infrastructure have been made in the literature so far, for example, the situation in the Ayia Napa (Sonmez et al., 2013), Lisbon (Nofre et al., 2018) or Barcelona (Nofre et al., 2017). 
Previous studies on Polish cities regarding changes in urban space related to tourism concerned mainly general touristification and gentrification issues, in particular such processes taking place in recent years in Cracow (e.g. Kubicki, 2017; Kruczek, 2018). Party tourism aspects of touristification were mainly discussed in the local press (e.g. Gąsior, 2014; Puto, 2017; Tymczak, 2018), and attempts to delimitate clubbing zones (Iwanicki, Dłużewska, 2014, 2015) did not contain such information. In particular, the issue of conflicts related to foreign party-goers concerns the public space of the most popular Polish party tourism destinations, which are Cracow and Warsaw (Iwanicki, Dłużewska, Smith, 2016; Thurnel-Read, 2012).

\section{Data and methods}

The methodology can be divided into three stages: (1) collecting data about clubs, pubs and bars; (2) determining before party and party zones; (3) identify the conflicts resulting from the popularity of party tourism in both cities.

Data regarding operating clubs in 2017 were collected through an inquiry on the clubbing.pl and ftb.pl websites. Information about the frequency of parties was obtained from official websites of the analyzed clubs.

The before party and party zones have been marked on the maps according to the method used by Somnez et al. (2013) and Nofre et al. (2018). In order to obtain a clear readability of the maps, before party zones contain only the boundaries without marking hundreds of pubs and bars. In the party zones the location of all 136 clubs is marked using QGIS programme (maps based on Apple Maps). Information about pubs and bars comes from the panoramafirm.pl website.

The identification of conflicts resulting from the popularity of party tourism in both cities occurred by querying the comments placed under the official accounts of selected clubs and pubs on the TripAdvisor and Facebook portals (comments up to 2017). Additional information was collected during on-site observations which took place six times in both cities in the years 2014-2017.

\section{Results}

\section{Clubs and zones}

Both cities have two main areas, which due to the high concentration of pubs, bars, cafes and restaurants can be called the before party zone. In Cracow, the main such zone is located in the Old Town, around the Main Square (fig. 1), and in terms of location it is almost identical to the main party zone which consists of 39 clubs (60\% of all clubs in Cracow) and covers an area of 58 hectares. The second place of high concentration of both pubs and clubs is located in the former Jewish district - Kazimierz, distant from the Main Square by over a kilometer. In terms of the number of clubs, this location is less important than the zone in Old Town and is popular mainly among local students, much less among tourists. 


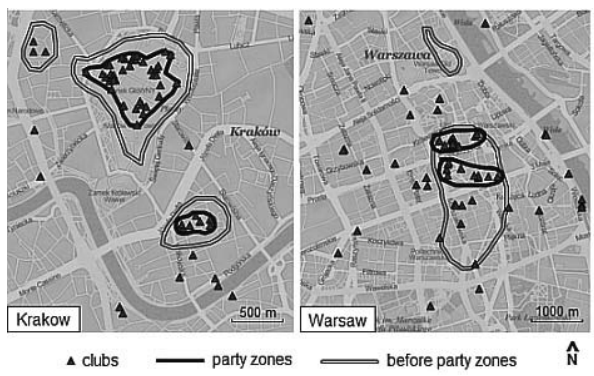

Figure 1. Clubs and zones in Cracow and Warsaw in 2017.

Source: own work.

As mentioned previously, in Warsaw, as well as in Cracow, two before party zones can be distinguished. The first one is located in the Old Town, the second one is much larger, however has a smaller concentration of pubs, and is located in the city center, on a vast area around the Palace of Culture and Science.

In contrast to Cracow, the Old Town is free from partying and clubbing, which is mainly concentrated in the city center. However, it is difficult to determine the boundaries of the party zone, because the clubs are scattered relatively loosely over the area of over 1,500 hectares, occupying almost the entire vast city center and reaching to the Vistula river banks. For this reason, the above map of clubs in Warsaw (fig. 1) has been prepared on a twice smaller scale in comparison to the map of Cracow, in order to correctly illustrate the issue. From this loose cluster two closely located zones can be specified, between the Saski Park and the above-mentioned Palace. In this area occupying over 130 hectares, there are 29 clubs out of 71 of all (40.8\%).

Despite the smaller overall number of clubs, the higher number of parties on weekdays is held in Cracow (tab. 1). Every day you can visit at least 26 clubs (on Sunday), which is almost nine times more than in Warsaw (only 3 open clubs on Monday). Taking into account the percentage of clubs open each day, Cracow is definitely outstanding.

Table 1. Frequency of parties in 2017

\begin{tabular}{|c|c|c|c|c|c|c|c|c|c|c|c|c|c|c|}
\hline \multicolumn{1}{|c|}{ city } & \multicolumn{2}{|c|}{ Monday } & \multicolumn{2}{c|}{ Tuesday } & \multicolumn{2}{c|}{ Wednesday } & \multicolumn{2}{c|}{ Thursday } & \multicolumn{2}{c|}{ Friday } & \multicolumn{3}{c|}{ Saturday } & \multicolumn{2}{c|}{ Sunday } \\
\hline & $\mathrm{n}$ & $\%$ & $\mathrm{n}$ & $\%$ & $\mathrm{n}$ & $\%$ & $\mathrm{n}$ & $\%$ & $\mathrm{n}$ & $\%$ & $\mathrm{n}$ & $\%$ & $\mathrm{n}$ & $\%$ \\
\hline Cracow & 27 & 41.5 & 30 & 46.1 & 36 & 55.4 & 47 & 72.3 & 63 & 96.9 & 65 & 100 & 26 & 40.0 \\
\hline Warsaw & 3 & 4.2 & 7 & 9.9 & 19 & 26.8 & 22 & 31.0 & 55 & 77.5 & 71 & 100 & 6 & 8.5 \\
\hline
\end{tabular}

Source: own work.

In the former capital city of Poland, on the least attractive days, at least $40 \%$ of clubbing facilities are open. If we consider this to be a model value, only Fridays and Saturdays meet this percentage criterion in Warsaw. Despite the fact that the capital city has slightly higher number 
of clubs (71 compared to 68 in Cracow) this figure refers to Saturday only. On other days of the week, especially on Mondays, Tuesdays and Sundays, few of them organise parties.

\section{Conflicts}

When viewing the comments on TripAdvisor and Facebook portals written by people who took part in parties in selected Warsaw and Cracow clubs, the similarity of discussed topics can be noticed. Most of the negative comments refer to annoying grappling or accosting of participants often by drunk groups of mostly British stag tourists. The complaints also concern loud behavior of such tourists in restaurants, and sometimes non-ordinary behaviors encountered in public places, in the vicinity of major tourist attractions. It should be emphasized that such comments are much more frequent in Cracow. In Warsaw, the complaints about letting drunk foreigners inside the prestigious clubs where selection is applied can be more often found. Commentators suspect that the owners of most clubs agree to such a situation because of money, concluding that foreign tourists will leave more money than local Polish partygoers.

During the observations conducted in both cities, there were clear differences. Groups of drunken and noisy tourists, mainly from the United Kingdom and other countries of Western Europe were much more often and clearly visible in Cracow. However, the unsuited behavior of these groups was evident mainly in the Main Square area and neighboring streets. The remaining area of the Old Town and the city center was relatively free of this type of groups.

In Warsaw, the situation with badly behaving foreign party tourists was completely different. The Old Town was almost completely free of such noisy groups, also on streets in the city center this problem seemed to be insignificant. Some vivid cases that occurred during the research were mainly encountered only directly in the queues at the entrances to the most popular clubs.

\section{Discussion and conclusions}

Despite a similar number of clubs in both cities (71 in Warsaw and 68 in Cracow), there are great differences in their clubbing infrastructure. The clubbing zone in Cracow can be clearly distinguished and it covers the greater part of the Old Town, almost entirely coinciding with the main part of before party zone. Such location of most clubs and pubs resembles the situation in Wroclaw (Iwanicki, Dłużewska, 2015). In turn, the clubbing zone in Warsaw is hardly noticeable, and the clubs are scattered over a large area covering almost the entire city center. In contrast to Cracow, the Warsaw Old City is free from clubbing. In this part of Warsaw there is the northernmost part of the before party zone, however, it is far from the place where the most clubs are concentrated.

Such differences in the clubbing infrastructure may affect more frequently negative incidents in Cracow related to the presence of foreign party tourists. In the Old Town of this city, which is the main tourist attraction and where most clubs are gathered, such situations are simply more visible and intense in contrast to the quieter Old Town in Warsaw. This is also influenced by smaller distances between particular clubs, and numerous apartments in the Old Town in which tourists spend their holidays, often drinking alcohol in those apartments as a part of a before party (instead 
of drinking in pubs). As a result, some groups of tourists traveling on foot from hotels towards the party zone are already very drunk and attract attention. In Warsaw, the distances between popular clubs and hotels are often so large that tourists use taxis, and because of this they might be less visible on the streets.

The impact on a larger number of negative incidents can be also related to much higher popularity of Cracow among party and stag tourists (Iwanicki et al., 2016; Thurnell-Read, 2012), as well as higher frequency of events throughout the week. In Warsaw, most clubs are open only on Saturday and Friday, while in Cracow every day at least nearly 30 of them are open, including most clubs in the party zone.

Is there a chance to solve a problem that seems to affect Cracow to a greater extent than Warsaw? Local officials and politicians could benefit from the experience of other cities struggling with the problem of troublesome party tourists (Colomb, Novy, 2016), introducing e.g.: a ban on the sale of alcohol at certain night hours in the Old Town, or introducing strict regulations regarding the short-term rental of apartments in representative parts of the city. The liquidation of clubs and discos in the Old Town of Cracow, as was the case in Warsaw, also could be an effective step. In the coming years, however, any major changes should not be expected, as it seems that Cracow authorities are not interested in changing city image (often associated with cheap fun and alcohol) due to huge income from weekend tourism.

\section{References}

Bavinton, N. (2010). Putting Leisure to Work: City Image and Representations of Nightlife. Journal of Policy Research in Tourism, Leisure \& Events, 2 (3), 236-250.

Boazman, S. (2010). Stag parties “fuels sex trafficking”. BBC News [online]. Retrieved from: http://news.bbc.co.uk/2/hi/ europe/8457172.stm (3.09.2018).

Briggs, D., Tutenges, S., Armitage, R., Panchev, D. (2011). Sexy substances and the substance of sex: Findings from an ethnographic study in Ibiza, Spain. Drugs and Alcohol Today, 4 (11), 173-187.

Colomb, C., Novy, J. (eds.) (2016). Protest and resistance in the tourist city. New York, NY: Routledge.

Dunne, G., Flanagan, S., Buckley, J. (2010). Towards an understanding of international city break travel. International Journal of Tourism Research, 5 (12), 409-417.

Gąsior, M. (2014). Brytyjscy turyści problemem Krakowa. NaTemat, 25.04.2014. Retrieved from: https://natemat. pl/99869, brytyjscy-turysci-problemem-krakowa-pijane-hordy-rzadza-na-ulicach (12.09.2018).

Goulding, C., Shankar, A. (2011). Club culture, neotribalism and ritualized behavior. Annals of Tourism Research, 4 (38), $1435-1453$.

Hadfield, P. (ed.) (2009). Nightlife and crime: Social order and governance in international perspective. Oxford: Oxford University Press.

Hughes, H., Allen, D. (2009). Central and Eastern Europe and EU accession 2004: Views of the impact on tourism. Tourism and Hospitality Research, 3 (9), 185-198.

Iwanicki, G., Dłużewska, A. (2014). Wybrane aspekty zagranicznej turystyki clubbingowej w Trójmieście. Turystyka kulturowa, 12, 38-53.

Iwanicki, G., Dłużewska, A. (2015). Potential of city break clubbing tourism in Wrocław. Biulletin of Geography. Socioeconomic Series, 28, 77-90.

Iwanicki, G., Dłużewska, A., Smith, M. (2016). Assessing the level of popularity of European stag tourism destinations. Questionnes Geographicae, 3 (35), 15-29. 
Kruczek, Z. (2018). Tourists vs. residents. The influence of excessive tourist attendance on the process of gentrification of historic cities on the example of Krakow. Turystyka Kulturowa, 3, 29-41.

Kubicki, P. (2017). Wpływ studentyfikacji i turystyfikacji na społeczno-kulturową przestrzeń miasta. Miasto. Pamięć i Przyszłość, 2, 63-73.

Laughey, D. (2006). Music and youth culture. Edinburgh: Edinburgh Press.

Lovatt, A., O’Connor, J. (1995). Cities and the Night-Time Economy. Planning Practice \& Research, 2 (10), $127-134$.

Malbon, B. (1999). Clubbing. Dancing, ecstasy and vitality. London: Routledge.

Nofre, J., Giordano, E., Eldridge, E., Martins, J.C. (2017). Tourism, nightlife and planning: challenges and opportunities for community liveability in La Barceloneta. Tourism Geographies, 3 (20), 377-396.

Nofre, J., Martins, J.C., Vaz, D., Fina, R., Sequera, J., Vale, P. (2018). The "Pink Street” in Cais do Sodré: urban change and liminal governance in a nightlife district of Lisbon. Urban Research \& Practice, 1-19.

Puto, K. (2017). "Cheap Eastern European Girls”, czyli tajlandyzacja magicznego Krakowa. Krytyka Polityczna, 18.08.2017. Retrieved from: http://krytykapolityczna.pl/felietony/kaja-puto/turystyka-krakow/ (13.09.2018).

Ravn, S. (2012). Contested identities: Identity constructions in a youth recreational drug culture. European Journal of Cultural Studies, 15, 513-525.

Smith, M., Puczko, L. (2010). Out with the old, in with the new? Twenty years of post-socialist marketing in Budapest. Journal of Town \& City Management, 1 (3), 288-299.

Sonmez, S., Apostolopoulos, Y., Teocharous, A., Massengale, K. (2013). Bar crawls, foam parties, and clubbing networks: Mapping the risk environment of Mediterranean nightlife resort. Tourism Management Perspectives, 8, 49-59.

Thurnell-Read, T. (2012). Tourism Place and Space. British stag tourism in Poland. Annals of Tourism Research, 2 (39), 801-819.

Tymczak, P. (2018). Kraków. Mieszkańcy: Mamy dość pijanych turystów. Kraków. Naszemiasto.pl., 19.01.2018. Retrieved from: http://krakow.naszemiasto.pl/artykul/krakow-mieszkancy-mamy-dosc-pijanych-turystowurzednicy,4381909, art,t,id,tm.html (12.09.2018).

https://pl.tripadvisor.com.

www.clubbing.pl.

www.facebook.com.

www.ftb.pl.

\section{IMPREZOWA PRZESTRZEN W KRAKOWIE I WARSZAWIE: IMPREZY I KONFLIKTY}

SŁOWA KLUCZOWE STRESZCZENIE clubbing, Kraków, turystyka klubowa, turystyka wieczorów kawalerskich, Warszawa

Miasta środkowoeuropejskie stały się popularnymi kierunkami dla turystów imprezowych po rozszerzeniu Unii Europejskiej w 2004 r. Wśród polskich miast, jednymi z najpopularniejszych tego typu destynacji stały się Kraków i Warszawa. Wraz ze wzrostem liczby turystów w obu tych miastach wzrosły dochody lokalnych przedsiębiorców, zwłaszcza właścicieli restauracji, barów i klubów, ale z czasem obecność wielu pijanych, często zachowujących się niestosownie turystów z zachodniej Europy stała się przyczyną konfliktów z lokalnymi mieszkańcami i innymi turystami. Do konfliktów tych dochodzi głównie w miejscach publicznych, w pobliżu miejsc o największej koncentracji barów i klubów. Takie miejsca można nazwać z ang. strefą before party (miejsca koncentracji barów i pubów) i strefą clubbingową (miejsca koncentracji klubów). W artykule zaprezentowane została delimitacja powyższych stref w Krakowie i Warszawie. 